COLLOQUIA THEOLOGICA OTTONIANA 2/2015, s. 239-248

DOI: $10.18276 /$ cto.2015.2-11

\author{
NOTY, KOMENTARZE, \\ RECENZJE, SPRAWOZDANIA
}

\title{
XII WALNE ZEBRANIE STOWARZYSZENIA BIBLISTÓW POLSKICH I 53. SYMPOZJUM BIBLISTÓW POLSKICH. TORUŃ, 22-24 WRZEŚNIA 2015 ROKU
}

\section{Tomasz Zaklukiewicz ${ }^{1}$}

Szczecin

W dniach 22-24 września 2015 roku w gmachu Wyższej Szkoły Kultury Społecznej i Medialnej w Toruniu odbyło się 53. Sympozjum Biblistów Polskich. Poprzedziło je XII Walne członków SBP.

Walne Spotkanie rozpoczęło się modlitwą, którą poprowadził w intencji obrad i za zmarłego w tym roku śp. ks. prof. Henryka Lempego - ks. prof. Henryk Witczyk.

Witając zebranych, przewodniczący podziękował za jedność Stowarzyszenia Biblistów Polskich jako szczególną cechę gremium. Następnie wspominając zmarłego ks. prof. Henryka Lempego, przypomniał jego drogę naukową; wskazał między innymi na jego uczestnictwo w sympozjach qumranologicznych. Podziękował też biblistom wrocławskim za reprezentowanie Zarządu na pogrzebie.

W dalszej części ks. H. Witczyk pogratulował belwederskich tytułów profesorskich, podając nazwiska tych biblistów, którzy je otrzymali. Następnie

1 Ks. dr Tomasz Zaklukiewicz, kapłan archidiecezji szczecińsko-kamieńskiej, dr nauk biblijnych; doktorat obronił na Wydziale Teologicznym Uniwersytetu Szczecińskiego w 2011 roku. Adres: Kuria Metropolitalna w Szczecinie, ul. Papieża Pawła VI nr 2, 71-459 Szczecin; e-mail: zakluk@ szczecin.opoka.org.pl. 
przewodniczący pogratulował kolejnych tytułów naukowych - habilitacji i doktoratów. Kolejnym punktem Walnego Zebrania było głosowanie nad nadaniem honorowego członkostwa SBP ks. prof. Antoniemu Troninie i wręczenie mu księgi pamiątkowej z okazji 70. rocznicy urodzin. Laudację osoby jubilata wygłosił ks. dr Mariusz Szmajdziński. Rozpoczął od przeczytania listów gratulacyjnych, m.in. kard. Gerharda Müllera, prefekta Kongregacji Nauki Wiary, kard. Gianfranco Ravasiego, prezydenta Papieskiej Rady Kultury, i abp. Stanisława Gądeckiego, przewodniczącego KEP. Po wysłuchaniu laudacji nastąpiło głosowanie nad nadaniem tytułu honorowego członkostwa SBP ks. profesorowi. Zebrani jednomyślnie opowiedzieli za nadaniem tego tytułu jubilatowi. Następnie ks. dr Mariusz Szmajdziński wręczył ks. A. Troninie księgę pamiątkową z okazji 70. rocznicy jego urodzin.

Po tej uroczystości ponownie głos zabrał przewodniczący stowarzyszenia, ks. prof. H. Witczyk. Najpierw podziękował za przygotowanie zeszłorocznego sympozjum w Łodzi. Jednocześnie usprawiedliwił nieobecność na tegorocznym sympozjum o. Klemensa Stocka SJ. W dalszej części swej wypowiedzi poinformował, że przyjęto pięciu nowych członków do stowarzyszenia i obecnie liczy ono 312 członków zwyczajnych SBP. Następnie podziękował wydawcom, redaktorom naczelnym i recenzentom wydawnictw za ich pracę i promowanie publikacji naukowych wszelkich stopni. Zwrócił się do autorów haseł biblijnych Encyklopedii katolickiej KUL. Wydawnictwo Naukowe KUL wraz z Wydawnictwem Jedność wydaje Nowy stownik teologii biblijnej, stąd potrzeba zgody autorów na ich opublikowanie. Przewodniczący poinformował, że pozytywnie złożony na KUL egzamin z języka hebrajskiego czy greckiego uprawnia do podjęcia studiów na Biblicum, bez konieczności podejmowania w Rzymie roku propedeutycznego. Na zakończenie podziękował za wkład wszystkim biblistom w rozwój nauk i zapowiedział termin następnego sympozjum, które odbędzie się 19-21 września 2016 roku w Rzeszowie.

Następnie głos zabrał skarbnik Stowarzyszenia, ks. prof. Wojciech Pikor. Przedstawił bilans minionego roku. Saldo wyniosło 690,35 zł. Sprawozdanie finansowe przyjęto jednogłośnie.

Pierwszy dzień sympozjum rozpoczęło się Mszą św., którą odprawił bp Andrzej Suski, biskup toruński. Wprowadzając do Mszy św., ks. prof. H. Witczyk przywołał patrona dnia św. o. Pio i polecił intencje modlitw, między innymi 50-lecie kapłaństwa księdza biskupa i dziękczynienie za natchnienie do pracy w minionym roku członków stowarzyszenia. W kazaniu celebrans odwołał się do 
osoby świętego, którego poznał osobiście. Przypomniał, że świętość to wysoka miara spraw codziennych i jesteśmy wezwani do niej wszyscy. Jest ona dana nam i zadana.

Po śniadaniu rozpoczęła się pierwsza sesja sympozjum. Została poświęcona Biblii Tysiąclecia, której 50-lecie pierwszego wydania obchodziliśmy w tym czasie. Poprowadził ją ks. prof. Roman Bartnicki.

Jako pierwszy głos zabrał ks. dr Romuald Pietkiewicz. Tematem jego wystąpienia było „Znaczenie Biblii Tysiąclecia dla kultury biblijnej w Polsce”. Wykład rozpoczął od genezy Biblii Tysiąclecia. Pomysł jej wydania wyszedł bezpośrednio od benedyktynów tynieckich. W roku 1959 na pierwszym formalnym zjeździe biblistów polskich udało się zebrać 39 tłumaczy ksiąg, co zaowocowało tym, że już w roku 1960 powstały pierwsze thumaczenia. Pierwsze wydanie Biblii Tysiąclecia ukazało się w 1965 roku, a pierwszy egzemplarz otrzymał kard. Stefan Wyszyński 2 sierpnia 1965 roku.

W dalszej części wykładu ks. R. Pietkiewicz omówił znaczenie Biblii Tysiąclecia dla Kościoła w Polsce po Soborze Watykańskim II. Najpierw wskazał na posoborową odnowę liturgiczną - czytania mszalne oparte są na Biblii Tysiąclecia, w obszarze duszpasterskim Biblia staje się codzienną lekturą dla wielu chrześcijan. Biblia Tysiąclecia ma wpływ na rozwój ruchu ekumenicznego w Polsce, stała się ona popularna również w kręgach niekatolickich. Warto zauważyć, że wydania protestanckie Pisma Świętego pojawiały się po wydaniu Biblii Tysiąclecia. Biblia tyniecka zrodziła też pomysł na Biblię ekumeniczną. Ks. R. Pietkiewicz podkreślił, że Biblia Tysiąclecia stała się textus receptus Biblii w języku polskim i najważniejszą księgą odnowy posoborowej. Dalej autor ukazał znaczenie Biblii Tysiąclecia dla polskiej tradycji przekładowej Pisma Świętego. Była pierwszym po 1632 roku przekładem na język polski i pierwszym przekładem katolickim całej Biblii z języków oryginalnych na język polski od 1599 roku. Siłą rzeczy Biblia Tysiąclecia wywarła wpływ na przekłady Pisma Świętego w XX i XXI wieku, takie jak Biblia warszawsko-praska (bp. K. Romaniuka), Biblia ekumeniczna czy Biblia Edycji św. Pawła. Nie bez znaczenia pozostaje to, że wraz z powstaniem Biblii Tysiąclecia została zarzucona tradycja tłumaczenia Biblii ks. Wujka, której język dla wielu współczesnych czytelników jest językiem anachronicznym. Zerwanie z tym stylem uwolniło rynek dla innych tłumaczeń współczesnych.

Od 1965 roku Biblia Tysiąclecia została wydana już w 4308500 egz., Nowy Testament - w 2139750 egz. Innych wydań było 1383673 egz. Ogółem wydano 781923 egz. Biblii Tysiąclecia. Nastąpił też rozwój jakościowy wydań: wydaje 
się ją drukiem tradycyjnym, w języku Braille'a, cyfrowo i w formie audio. Warto zauważyć różnorodność form wydawniczych: standardowe formaty wydawnicze, w których ukazuje się Biblia Tysiąclecia, to A4, A5+, A6.

Biblia Tysiąclecia zastosowała nowy model edytorski, oparty na modelu Biblii Jerozolimskiej. Polega on na układzie graficznym poszczególnych wydań: tekst jest podany w jednej lub dwóch kolumnach, cytaty pisane są kursywą, przypisy i sigla biblijne znajdują się na dole strony, wprowadzono podział na tytuły. Każda księga opatrzona jest wstępem, który drukowany jest kursywą na jej początku.

Nad przekładem ksiąg biblijnych pracował zespół tłumaczy. Rozwój zespołowej metody pracy nad przekładami wynika z uzasadnienia o. A. Jankowskiego: do przekładu Biblii wymagana jest wiedza przekraczająca możliwości jednego człowieka i zespołowa metoda pracy odpowiada samej naturze Biblii, która jest zbiorem ksiąg wielu ludzi.

Biblia Tysiąclecia przyczyniła się też do rozwoju biblistyki w Polsce. Rozwijająca się jakość i liczba tłumaczeń świadczą o rozwoju kultury biblijnej, a to podnosi znajomość Pisma Świętego. Reasumując, ks. dr R. Pietkiewicz zacytował ks. prof. Jana Kantego Pytela, cenzora trzeciego wydania Biblii Tysiąclecia, który napisał w liście do abp. Jerzego Stroby, że Biblia Tysiąclecia:

a) jest wielkim osiągnięciem w dziedzinie wiedzy biblijnej;

b) kształtuje życie kościelne;

c) przygotowana jest z ogromną odpowiedzialnością i dojrzałością naukową;

d) w całym tłumaczeniu są staranne przekłady, dobre objaśnienia i słownik pojęć biblijnych.

Drugim prelegentem pierwszego dnia był ks. Zbigniew Rembisz, dyrektor Wydawnictwa Pallottinum. W swym wystąpieniu zajął się tematem „Edycja Biblii Tysiąclecia - historia i perspektywy”. Omówił sposoby pracy nad Biblią Tysiąclecia. Wysoko ocenił wspólną pracę zespołu o. A. Jankowskiego. Korekta i praca nad BT stała się dla Pallottinum przyczynkiem rozwoju wydawnictwa. Ze względu na Biblię Tysiąclecia wydawnictwo przekształciło się, jak to nazwał, w drukarnię ,papierów wartościowych”. W związku z wydawaniem Biblii Tysiąclecia Pallottinum stworzyło na nowo całą linię produkcyjną.

Na zadane przez prelegenta pytanie: „Czy wydawnictwo Pallottinum wywiązało się z powierzonego zadania?”, uczestnicy sympozjum odpowiedzieli gromkimi brawami. W dalszej części swej wypowiedzi ksiądz dyrektor zwrócił się do członków Stowarzyszenia Biblistów Polskich z prośbą o powołanie nowej redak- 
cji naukowej Biblii Tysiąclecia, która podjęłaby pracę nad nowymi wydaniami Biblii Tysiąclecia.

Złoty jubileusz pierwszego wydania Biblii Tysiąclecia Pallottinum uczciło wydaniem nowego Komentarza teologiczno-pastoralnego do BT. Praca nad nim trwała 5 lat.

Odpowiadając na zaproszenie ks. dyr. Z. Rembisza, ks. prof. H. Witczyk obiecał omówienie na najbliższym Zarządzie SBP powołania redakcji naukowej Biblii Tysiąclecia.

Kolejnej sesji przewodniczył o. Tomasz Dąbek OSB. Pierwszy wykład wygłosił ks. Jacek Nowak SAC na temat „Biblia Tysiąclecia w liturgii”. Przypomniał, że język werbalny w liturgii odgrywa ważną rolę, na co zwrócił uwagę Sobór Watykański II, zezwalając na używanie w liturgii, obok łaciny, języka ojczystego. W tym miejscu prelegent przedstawił historię tłumaczeń tekstów i czytań liturgicznych. Wraz z reformą papieża Pawła VI decyzją Prymasa Tysiąclecia należało przygotować teksty lekcjonarza, opierając się na tekstach Biblii Tysiąclecia. W związku z tym, że tekst psalmów tam zawartych nie nadawał się do śpiewania, o. Placyd Galiński i Marek Skwarnicki opracowali go na nowo. W tekstach wprowadzane są na bieżąco zmiany, dostosowywane do współczesnego języka i realiów języków oryginalnych.

Ks. J. Nowak zapowiedział, że nowy lekcjonarz z ujętymi zmianami ukaże się we wspomnienie liturgiczne św. Jana Pawła II w październiku 2015 roku. Będzie w trzech wielkościach. Wprowadzone zmiany językowe są zgodne z 5 wydaniem Biblii Tysiąclecia. Podobne zmiany będzie mieć nowa Liturgia Godzin, która ukaże się w 2016 roku. Oprócz tego tekst Biblii Tysiąclecia wykorzystywany jest w redakcji różnego rodzaju modlitewników.

Kolejnym prelegentem był dr hab. Grzegorz Kubski z UAM w Poznaniu, który zajął się tematem: „Tyniecki przekład Ewangelii wobec koniunktur kultury religijnej”. W swoim wystąpieniu przypomniał, że w naszej kulturze pojęcie „Biblia Tysiąclecia” jest pojęciem jasnym. Odnosząc się do tematu wykładu, prelegent wskazał, że Ewangelia, jak każdy gatunek biblijny, jest ujęta w pewne reguły formalne. Jest zbiorem mów sakralnych. Polszczyzna biblijna i jej piękno widoczna jest w wielu przekładach. Niestety, nie udało się tego ukazać w Biblii Tysiąclecia, w której dominuje styl oficjalny. W dalszej części swej wypowiedzi G. Kubski omówił stylistykę i retorykę Ewangelii w Biblii Tysiąclecia i porównał je $\mathrm{z}$ innymi thumaczeniami. 
$\mathrm{Na}$ zakończenie tej części spotkania ks. prof. J.K. Pytel, jako świadek tych wydarzeń, szeroko wspominał pracę nad thumaczeniem i wydaniem Biblii Tysiąclecia.

Po jego wystąpieniu nastąpiło wręczenie dyplomów honorowych członków SBP: księżom prof. Tomaszowi Jelonkowi i prof. Antoniemu Troninie.

Popołudniowej, III sesji przewodniczył ks. dr hab. Zdzisław Żywica. Pierwszym prelegentem był ks. dr Adam Węgrzyn SDB, którego temat wystąpienia brzmiał: „Kim jest Ten, który i grzechy odpuszcza? Analiza narracyjna Łk 7,36-50". Autor dowodził, że narrator opowiadania prowadzi czytelnika w sposób zaplanowany. Najpierw przedstawia faryzeusza, gospodarza domu, potem grzesznicę, która obmywa stopy Jezusowi. W perykopie najważniejszym jest pytanie: „Kim On jest?”. To wie tylko kobieta, inni tego nie wiedzą i nie rozumieją. Czytelnik Ewangelii początkowo utożsamia się z postawą kobiety. W dalszej części narracji miejsce faryzeusza i grzesznicy zajmuje sam czytelnik, który musi sobie odpowiedzieć na to pytanie.

Następnym prelegentem był ks. dr hab. Stanisław Wronka z UPJP II w Krakowie, przedstawiający temat: „Pozycja kobiety w małżeństwie w świetle tablic domowych NT (Kol 3, 18; Ef 5, 21-33; 1 P 3, 1-6; Tt 2,5)".

Autor wykazał, że tzw. tablice domowe są łatwe do wyodrębnienia z tekstu. Sugeruje to, że zostały one włączone do listów Pawłowych. Taki wniosek można wyprowadzić z kontekstów bliższego i dalszego. W swoim wykładzie ks. S. Wronka skupił się na kwestii podporządkowania żony mężowi. Papieska Komisja Biblijna (132) zwraca uwagę na trudność w odczytaniu tych fragmentów przez współczesnych, gdyż podporządkowanie żon straciło dziś na aktualności. Św. Paweł w swych listach dostosowuje się do zwyczajów greckich i rzymskich, podkreślając, że podporządkowanie to wynika z miłości do męża, a nie z powodów społecznych. Powodem jest porównanie miłości Chrystusa do Kościoła z Listu do Efezjan. Prelegent wyjaśnił kontekst poszczególnych wypowiedzi występujących w poszczególnych tablicach domowych. W konkluzji stwierdził, że interpretacja dosłowna jest nie do przyjęcia. Wszyscy są sobie równi, poddanie należy traktować tu relatywnie. Hagiograf zachęca do takiego życia, by spotkać się z Chrystusem. Teksty te należy interpretować zgodnie z duchem Ewangelii.

Kolejny wykład wygłosił ks. prof. Bogdan Poniży z UAM w Poznaniu, który zajął się tematem „Uosobiona Mądrość w Sophia Salomonos”.

W swoim przedłożeniu ks. profesor przypomniał, że Księga Mądrości głosi naukę o nieśmiertelności. Uosobiona Mądrość obiecuje życie tym, którzy będą jej 
szukać i zgodnie z nią postępować. Księga przynosi ostateczne rozwiązanie trudnego problemu, jakim jest śmierć sprawiedliwego. Największym darem dla człowieka jest nieśmiertelność, która jest nagrodą za wierność Bogu. Podobieństwo do Boga zawarte w Księdze Rodzaju autor interpretuje jako powołanie do nieśmiertelności. Taką teologię dała myśl hebrajska. Hellenizm natomiast zaproponował określenia: - aftarsia i atanasia - niezniszczalność i nieśmiertelność. Co wnosi w świat takich pojęć Księga Mądrości? Czy wnosi wierzenia ze świata zewnętrznego, gdzie panował kult bogini mądrości? Mędrzec denacjonalizuje orędzie Starego Testamentu. Duchowe wartości Izraela stają się udziałem ludzi dobrej woli. Następuje wyraźna indywidualizacja odpowiedzialności za swoje czyny. Miejsce Izraela zajmuje w księdze pojedynczy sprawiedliwy. W konkluzji ks. profesor zauważa, że bazując na teologii Starego Testamentu i korzystając z pojęć hellenistycznych, hagiograf jako Izraelita wnosi swoje uniwersalistyczne poglądy do świata hellenistycznego, wskazując, że Mądrość to zbawca, ma w sobie coś boskiego, wywodzi się od Boga, była przed stworzeniem świata, decyduje o życiu i śmierci człowieka (Prz 8, 22-31). Personifikacja Mądrości stanowi gotowe tworzywo do przedstawienia Wcielenia w Nowym Testamencie.

Dzień kolejny rozpoczął się Mszą św., której przewodniczył ks. prof. Janusz Kręcidło. Kazanie wygłosił ks. prof. Stanisław Hałas. Przypomniał, że jesteśmy zobowiązani do głoszenia prawdy, która łączy się z natchnieniem.

Sesji I drugiego dnia przewodniczył ks. dr hab. Grzegorz Szamocki. Pierwszym wykład wygłosił ks. prof. Waldemar Chrostowski z UKSW z Warszawy na temat: „Problem historyczności Księgi Jonasza: «kompozycja wyobrażona»?”. Rozpoczynając, zadał pytanie będące podstawowym dylematem zajmujących się Biblią: „Czy to, o czym traktują teksty biblijne, wydarzyło się naprawdę?”. Przypomniał, że Księga Jonasza znajduje się zbiorze ksiąg prorockich. Sam Jezus odsyła do tej księgi. Jednakże w księdze znajdują się teksty, których nie można traktować historycznie. Komisja Biblijna w swym dokumencie stoi na stanowisku, że treść Księgi Jonasza jest kompozycją wyobrażoną, a nie historyczną. Według Chrostowskiego chodzi w niej o to, że hagiograf kieruje swoje słowa do członków wspólnoty żydowskiej, a nie do Niniwitów. Wykładowca postawił tezę, że jest to opowiadanie, które nigdy się nie wydarzyło, ale niesie w sobie wiele prawd dydaktycznych. Pytanie: w jakim języku Jonasz zwracał się do pogańskich mieszkańców Niniwy? Jeśli przyjmiemy wersję thumaczenia, że mieszkańcy uwierzyli „Bogu”, a nie „w Boga”, to przyjmujemy zwrot zakładający wcześniejszą wiarę słuchaczy. W całej Biblii Hebrajskiej konstrukcja „zawierzyć Bogu” odnosi się 
tylko do narodu, nigdy zaś do narodów pogańskich. Jonasz wzywałby wtedy do właściwego życia swych pobratymców. Kolejnym problemem to określenie „król Niniwy”. Nigdy nie określano króla asyryjskiego tytułem „król Niniwy”.

W konkluzji ks. profesor stwierdził, że Jonasz podejmuje misję proroków Izraela. Gdy nastała diaspora, uczynił swoich rodaków odbiorcami orędzia, wzywał do nawrócenia Izraelitów, a nie pogan.

Kolejny wykład miał ks. dr Mariusz Szmajdziński, który mówił o „Dniu Pańskim w nauczaniu Dwunastu Proroków”.

W swoim wystąpieniu stwierdził, że „Dzień Jahwe” to boska interwencja w ludzkie dzieje. Określenie Jom Jahwe pojawia się w Biblii 15 razy. Wszystkie występują w księgach prorockich, głównie proroków mniejszych. Inne określenie to „Dzień Gniewu”, występuje ono 3 razy, w większości w zbiorze 12 proroków.

Jakie są elementy konstytutywne Dnia Pańskiego? Teksty opisują go zwięźle, najczęściej są to dwa, trzy wersy. Zawsze ukazani są ci, których on dotyczy. Jednocześnie ukazane są też powody występowania Dnia Pańskiego. Może stanowić karę, ale może mieć aspekt pozytywny. Łączy się wtedy z oczyszczeniem, nawróceniem. Adresatem jest naród wybrany lub narody pogańskie. Ks. doktor ukazał w dalszej części swego wystąpienia, jak poszczególni prorocy opisują i rozumieją ideę Dnia Pańskiego.

Resumując, prelegent wskazał, że Dzień Pański jako idea teologiczna jest bardzo żywy i wielobarwny. Stanowi przejście od rzeczywistości ziemskiej ku eschatologicznej.

Kolejnej sesji przewodniczył ks. prof. Józef Kozyra. Jako pierwszy głos zabrał dr hab. Krzysztof Mielcarek z KUL. Jego wykład dotyczył tematu: „Ewangelie dzieciństwa. Między Scyllą faktografii i Charybdą mitu”.

$\mathrm{Na}$ wstępie prelegent przypomniał, że metoda historyczna nakazuje szukać dwóch niezależnych źródeł omawianego dzieła. Natomiast wiele wydarzeń z dzieciństwa Jezusa ma tylko jedno źródło. Są nimi Ewangelie. Mateusz i Łukasz nie podają, skąd mają swoje informacje. Trudno traktować te obie Ewangelie jako podejście kronikarskie. Można dokonać ich harmonizacji tylko do pewnego stopnia. Natomiast faktograficzne odniesienie do Ewangelii dzieciństwa może doprowadzić do zagubienia perspektywy tajemnicy wiary. Gdyby wprowadzić pojęcie mitu, to nie wyczerpuje ono koncepcji Ewangelii dzieciństwa. Byłby to tekst gnostycki. Obraz Chrystusa wiary zakłada istnienie Jezusa historii. Byłaby to koncepcja mitu, który stał się historią. 
Przekład Ewangelii dzieciństwa pokazuje, że lektura Ewangelii w konfrontacji z historycznymi faktami nie jest łatwa. Próba siłowego godzenia tekstu z faktami może przynieść szkody czytelnikowi i samemu tekstowi. Egzegeta powinna mieć na uwadze cel - jest nim osobista więź z Bogiem i podzielenie się nią z innymi.

Kolejnym prelegentem był prof. dr hab. Krzysztof Pilarczyk z UJ. Temat jego wystąpienia brzmiał: „Dzieje a początki Kościoła: wokół problemu datacji dzieła Łukasza”. Autor w swym wykładzie podjął się próby przesunięcia datacji dzieła Łukaszowego na czas późniejszy. Kiedy powstało? Według niego ok. pierwszej poł. II wieku albo 80 roku, albo w latach 90-95. Niektórzy współcześni badacze uważają, że Dzieje Apostolskie napisane zostały ok. 110-130 roku.

Konsekwencje późnej datacji: widać, że autor jest doskonałym narratorem. Jedynym źródłem byłyby listy św. Pawła. Wtedy narracja Dz 1-7 ma niewielką wartość historyczną. Dlatego też na podstawie Dziejów Apostolskich nie powinno układać się biografii św. Pawła. Dzieje nie są księgą historyczną. Autor Dziejów wywodziłby się ze świata grecko-rzymskiego i byłby postacią anonimową.

Spotkanie zakończyło się podaniem daty i miejsca przyszłorocznego spotkania: odbędzie się ono w Rzeszowie w dniach 19-21 września 2016 roku. 
